\title{
Direct detection of unamplified spring viraemia of carp virus RNA using unmodified gold nanoparticles
}

\author{
Mona Saleh, Hatem Soliman, Oskar Schachner, Mansour El-Matbouli* \\ Clinical Division of Fish Medicine, Department for Farm Animals and Veterinary Public Health, \\ University of Veterinary Medicine, Veterinaerplatz 1, Vienna 1210, Austria
}

\begin{abstract}
Spring viraemia of carp (SVC) is a viral disease that mainly affects carp Cyprinus carpio and other cyprinid fish, causing severe economic losses. Rapid detection and identification of spring viraemia of carp virus (SVCV) is crucial for effective disease management. Recent advances in nanoscience are having a significant impact on many scientific fields, especially biodiagnostics, where a number of nanoparticle-based assays have been introduced for biomolecular detection. Single- and double-stranded oligonucleotides can be adsorbed on gold nanoparticles (AuNPs) in colloidal solution under certain conditions. We exploited this phenomenon to develop a specific hybridization assay for direct detection of SVCV-RNA without prior amplification. The result of the hybridization process could be detected visually within 1 min when the colour of the reaction mixture changed from red to blue (positive reaction) or remains red (negative). The lower detection limit of the assay was estimated to be $10^{-3} \mathrm{TCID}_{50} \mathrm{ml}^{-1}$ SVCV-RNA, and it has the feasibility to detect the target virus-RNA in clinical specimens without previous amplification. In order to obtain an indication of the assay's performance on clinical samples we compared the optimized assay with nested RT-PCR in detection of SVCV-RNA in infected fish samples. The concordance of the 2 methods was defined as $100 \%$ when compared to nested RT-PCR positive and negative samples. The SVC-AuNPs assay requires only $15 \mathrm{~min}$, eliminates the need for thermal cycling or detection instruments and is a specific and rapid tool for detection of SVCV-RNA directly from clinical samples.
\end{abstract}

KEY WORDS: SVCV $\cdot$ AuNPs $\cdot$ Colorimetric detection $\cdot$ Diagnosis

\section{INTRODUCTION}

Spring viraemia of carp (SVC) is an infectious disease that affects common carp Cyprinus carpio carpio and other cyprinid species. The etiological agent of SVC is the spring viraemia of carp virus (SVCV), also known as Rhabdovirus carpio (Fijan et al. 1971, Bachmann \& Ahne 1973). SVCV is a member of the genus Vesiculovirus, in the family Rhabdoviridae. The disease is widespread in European carp culture, where it causes significant morbidity and mortality (Ahne et al. 2002). SVCV has also been isolated in the USA, Canada and China, which signals the broad occurrence and continued expansion of this notifiable disease (Goodwin 2002, Liu et al. 2004, Garver et al. 2007, Teng et al. 2007). The disease causes severe losses in juvenile carp with a mortality rate of 30 to $70 \%$ at water temperatures of 10 to $17^{\circ} \mathrm{C}$, typically during spring outbreaks (Ahne et al. 2002). At higher temperatures, infected carp develop humoral antibodies that can neutralize the spread of the virus and such carp are protected against reinfection by solid immunity (Ahne et al. 2002). Standard diagnosis of SVCV is commonly achieved by virus isolation followed by several confirmatory assays, such as serum neutralization, immunofluo- 
rescence, immunoperoxidase, and ELISA (Amos 1985, OIE 2009). Rapid advances in molecular biology techniques have led to the development of several molecular methods for SVCV detection, including hybridization assays, RT-PCR, nested RT-PCR (nRT-PCR) and real-time PCR (Oreshkova et al. 1999, Koutná et al. 2003, Yue et al. 2008). Although these assays are specific and sensitive, they are time consuming and require sophisticated apparatus and complex post-run manipulations.

Recently, noble metal nanoparticles, particularly gold nanoparticles (AuNPs), have been introduced as a promising approach to the development of the next generation of diagnostic assays (Mirkin et al. 1996, Storhoff et al. 2000). AuNPs have become an important alternative as imaging agents due to their noncytotoxicity, facile immunotargeting and nonsusceptibility to photobleaching or chemical/thermal denaturation, a problem commonly associated with dyes (Jain et al. 2006). Advances in functionalizing particles with oligonucleotides and tailoring their surface properties have paved the way to design a series of new and practical systems for nucleic acid detection (Mirkin et al. 1996, Elghanian et al. 1997, Storhoff et al. 2000, Daniel \& Astruc 2004, Thaxton et al. 2006). The colour change of colloidal AuNPs associated with the transition from a dispersed to an aggregated state, along with the corresponding shift of surface plasmon absorption, has been utilized for colorimetric DNA and RNA detection (Elghanian et al. 1997, Nam et al. 2003, Sato et al. 2003, Huber et al. 2004, Katz \& Willner 2004, Li \& Rothberg 2004, Rosi \& Mirkin 2005). Colloidal solutions of spherical AuNPs are typically red and change to blue upon aggregation. Addition of salt shields the negatively charged surface of colloidal gold solutions, resulting in aggregation of the AuNPs and a red to blue colour shift that can be monitored even with the naked eye at nanomolar concentration (Mirkin et al. 1996).

AuNP-based DNA diagnosis can be generally classified as either being labelled or label-free (Lee et al. 2008). In the labelled method, AuNPs are modified mainly with thiolated single stranded DNA (ssDNA) and then allowed to hybridize with a complementary target DNA sequence (Mirkin et al. 1996). However, the need for pre-modification of the AuNPs makes this strategy laborious, complicated and timeconsuming (Jung et al. 2010). The label-free method for DNA detection takes advantage of the different electrostatic properties of ssDNA and double-stranded DNA (dsDNA). Since ssDNA is flexible and can partially uncoil, it can easily be adsorbed on AuNPs and enhance electrostatic repulsion between AuNPs, which in turn stabilizes AuNPs even in the presence of salt. In contrast, because dsDNA cannot easily uncoil and has an exposed negatively charged phosphate backbone, the strong repulsion between dsDNA and AuNPs prevents the adsorption of the dsDNA and salt-induced aggregation is not blocked (Watson 1968, Bloomfield et al. 1999, Li \& Rothberg 2004). When AuNPs are added to a saline solution containing the target nucleic acid and its complementary unlabeled ssDNA probe, AuNPs aggregate since the probes are not free to stabilize the AuNPs and the solution colour changes to blue. Conversely, in the absence of the target nucleic acid or in the presence of a non-complementary target, the probes are free to stabilize the AuNPs, thus preventing aggregation and the solution colour remains red. This phenomenon was used to design various label-free techniques for detection of specific DNA and RNA sequences (Li \& Rothberg 2004, 2005, Shawky et al. 2010).

In our study, a rapid and reliable AuNP-based colorimetric assay was developed for direct detection of SVCV-RNA without prior amplification (Fig. 1).

\section{MATERIALS AND METHODS}

\section{Viruses and cell cultures}

SVCV isolates and the reference strain used in this study are listed in Table 1. The isolates were inoculated onto an epithelioma papulosum cyprinid (EPC) cell line maintained in Eagle's minimal essential medium (EMEM) buffered to $\mathrm{pH} 7.6$ with sodium bicarbonate, supplemented with $2 \%$ foetal bovine serum (FBS) and standard concentrations of antibiotic. The inoculated cultures were incubated at $15^{\circ} \mathrm{C}$. When advanced cytopathic effect (CPE) was observed, the cell culture supernatants were harvested for RNA extraction.

\section{RNA extraction}

Viral genomic RNA was extracted using QIAamp Viral RNA Kit (Qiagen) according to the manufacturer's instructions. RNA was also extracted from uninfected EPC cells as a negative control. Suspected SVC fish tissues homogenates were subjected to RNA extraction using RNeasy kit (Qiagen) as per the manufacturer's instructions. Purified RNAs were quantified by measuring the optical density at 260 and $280 \mathrm{~nm}$ and stored at $-80^{\circ} \mathrm{C}$ in aliquots until required. 
Non-complementary RNA

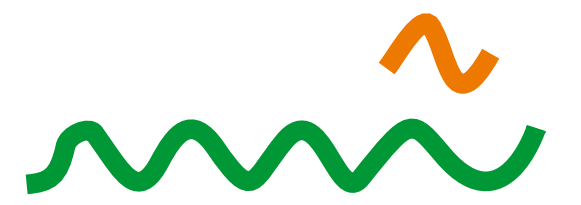

$\square$
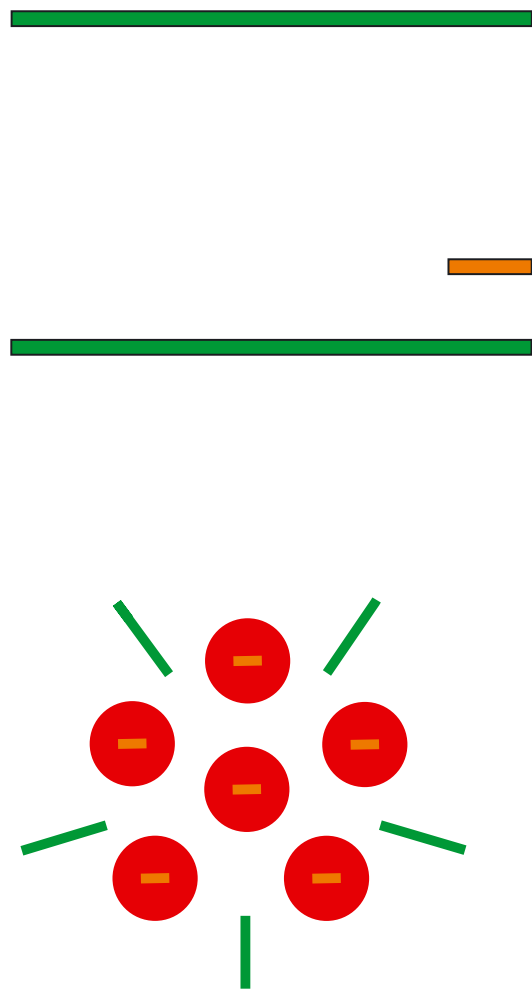

Stabilization of the AuNPs due to adsorption of the probe on its surface: colour of the AuNPs remains red
Complementary RNA

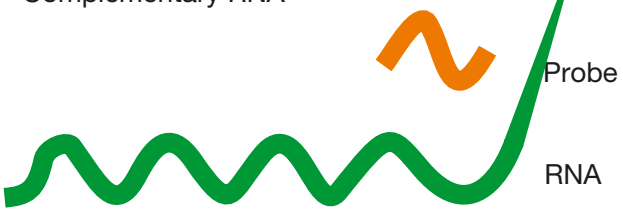

Denaturation

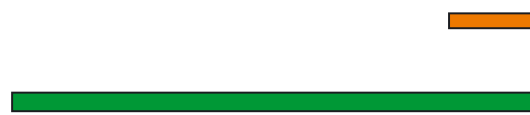

Annealing

\section{Addition}

of

AuNPs

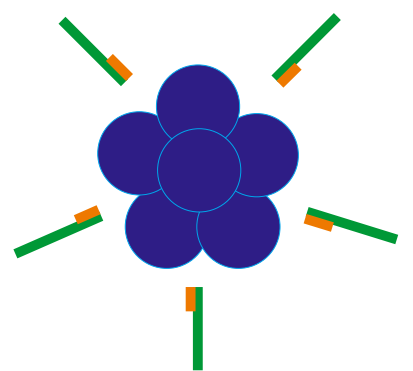

Aggregation of AuNPs because the probe is not free to stabilize the AuNPs: colour shift from red to blue

Fig. 1. Colorimetric assay based on unmodified gold nanoparticles (AuNPs) for detection of spring viraemia of carp virus (SVCV)-RNA. First, the target RNA is denatured and the complementary probe hybridizes to the target forming double strands. When AuNPs are added, the solutions change from red to blue because the probe is not free to stabilize the AuNPs. In the presence of a non-complementary target RNA, the probe will be free to adsorb onto and stabilize the AuNPs, consequently preventing their aggregation, and the solution colour remains red

\section{nRT-PCR}

Detection of SVCV RNA was carried out according to Koutná et al. (2003) with some modification. Briefly, the 1-step RT-PCR was performed using QIAGEN ${ }^{\circledR}$ OneStep RT-PCR Kit. In a $50 \mu$ reaction volume, $1 \mu \mathrm{g}$ RNA was mixed with 5x QIAGEN
OneStep RT-PCR buffer, dNTPs mix, 20 pmol of each external primer pair, RNase inhibitor, $2 \mu \mathrm{l}$ QIAGEN OneStep RT-PCR Enzyme Mix, and RNase-free water. Reaction conditions were as follows: incubation at $50^{\circ} \mathrm{C}$ for $30 \mathrm{~min}$, then $95^{\circ} \mathrm{C}$ for $15 \mathrm{~min}$, followed by $35 \mathrm{cycles}$ of $94^{\circ} \mathrm{C}$ for $30 \mathrm{~s}, 50^{\circ} \mathrm{C}$ for $1 \mathrm{~min}$, and $72^{\circ} \mathrm{C}$ for $1 \mathrm{~min}$, and a final extension 
Table 1. Viral strains used to test the specificity and validate the colorimetric spring viraemia of carp virus (SVCV)-RNA assay utilizing unmodified gold nonparticles (AuNPs). Viruses tested for specificity were the epizootic haematopoietic necrosis virus (EHNV), infectious haematopoietic necrosis virus (IHNV), infectious salmon anaemia virus (ISAV), koi herpes virus (KHV), viral hemorrhagic septicaemia virus (VHSV), pike fry rhabdovirus (PFRV), and zander rhabdovirus (ZRV). +: positive result; - : negative result

\begin{tabular}{|lcccccc|}
\hline Virus & Strain & Host & & Origin & SVCV-AuNPs assay result & Source \\
\hline SVCV & A-92/94, ld1 & Koi carp & Cyprinus carpio koi & Austria & + & Present study \\
SVCV & A-10/07 & Koi carp & Cyprinus carpio koi & Austria & + & Present study \\
SVCV & A-73/3, ld2 & Koi carp & Cyprinus carpio koi & Austria & + & Present study \\
SVCV & A-122/02 & Common carp & Cyprinus carpio carpio & Austria & + & Present study \\
SVCV & A-100/03 & Common carp & Cyprinus carpio carpio & Austria & + & Present study \\
SVCV & A-38/07 & Common carp & Cyprinus carpio carpio & Austria & + & Present study \\
SVCV & A-60/07 & Common carp & Cyprinus carpio carpio & Austria & + & Present study \\
SVCV & A-203/08 & Common carp & Cyprinus carpio carpio & Austria & + & Present study \\
SVCV & $56 / 70$ & Common carp & Cyprinus carpio carpio & Yugoslavia & + & Fijan et al. (1971) \\
EHNV & $86 / 8774$ & Rainbow trout & Oncorhynchus mykiss & Australia & - & Langdon et al. (1988) \\
IHNV & $217 / A$ & Rainbow trout & Oncorhynchus mykiss & Italy & - & Bovo et al. (1987) \\
ISAV & Glesvaer 2/90 & Atlantic salmon & Salmo salar & Norway & - & Present study \\
KHV & $07 / 108 b$ & Koi carp & Cyprinus carpio koi & France & - & J. Casteric (unpubl.) \\
PFRV & PFR 50 & Northern pike brood & Esox lucius & Germany & - & Present study \\
VHSV & DK-5151 & Rainbow trout & Oncorhynchus mykiss & Denmark & - & Olesen et al. (1993) \\
ZRV & ZR93 & Zander brood & Sander lucioperca & Germany & - & V. Pohle (unpubl.) \\
\hline
\end{tabular}

step of $72^{\circ} \mathrm{C}$ for $10 \mathrm{~min}$. Following the 1 -step RTPCR, the nested PCR was carried out in $50 \mu l$ reaction volume utilizing $2 \times$ ReddyMix $^{\mathrm{TM}}$ PCR Master Mix (Thermo Scientific), which contained $75 \mathrm{mM}$ Tris- $\mathrm{HCl}$ (pH 8.8), $20 \mathrm{mM}\left(\mathrm{NH}_{4}\right)_{2} \mathrm{SO}_{4}, 1.5 \mathrm{mM}$ $\mathrm{MgCl}_{2}, 0.01 \%$ Tween-20, $0.2 \mathrm{mM}$ each nucleotide triphosphate, $1.25 \mathrm{U}$ thermoprime plus DNA polymerase, and red dye for electrophoresis, $2 \mu \mathrm{l}$ of the 1-step RT-PCR product and 50 pmol each of internal primers (Table 2). The cycling profile was $94^{\circ} \mathrm{C}$ for $3 \mathrm{~min}$, then $35 \mathrm{PCR}$ cycles of $94^{\circ} \mathrm{C}$ for $30 \mathrm{~s}$, $55^{\circ} \mathrm{C}$ for $30 \mathrm{~s}$ and $72^{\circ} \mathrm{C}$ for $30 \mathrm{~s}$, with a terminal extension step of $72^{\circ} \mathrm{C}$ for $7 \mathrm{~min}$. PCR products were analysed by gel electrophoresis using $2 \%$ agarose in Tris acetate-EDTA buffer (0.04 M Tris acetate, $1 \mathrm{mM}$ EDTA), stained with ethidium bromide and visualized on an UV transilluminator. A Quick-load 100 bp DNA ladder (New England BioLabs) was used to determine the size of the PCR products. The amplified products were purified using a MinElute PCR purification kit (Qiagen) according to the manufacturer's instructions and sequenced via commercial automated sequencing service (LGC genomics).

\section{Preparation of gold nanoparticles}

A colloidal solution of AuNPs with a mean $( \pm$ SD) diameter of $15 \pm 2 \mathrm{~nm}$ was prepared by the citrate reduction method described by Grabar et al. (1995). Briefly, an aqueous solution of $\mathrm{HAuCl}_{4} \cdot 3 \mathrm{H}_{2} \mathrm{O}(1 \mathrm{mM}$, $100 \mathrm{ml}$ ) was brought to a vigorous boil while stirring, then $10 \mathrm{ml}$ of $1 \%$ trisodium citrate $(38.8 \mathrm{mM})$ were added quickly, which resulted in a change in solution colour from pale yellow to deep red. The mixture was refluxed for 15 min with continuous stirring. The colloidal solution was then allowed to cool at room temperature and transferred into a clean glass bottle and stored in the dark until use.

Table 2. Primers and probe used in this study according to the spring viraemia of carp virus (SVCV) reference strain (GenBank Accession: U18101.2). AuNPs: gold nanoparticles; nt: nucleotides

\begin{tabular}{|llcc|}
\hline Oligonucleotide name & Sequence (5' to $\left.3^{\prime}\right)$ & Position (bp) & Length (nt) \\
\hline External sense primer & GCC TAA ATG TGT TGA TGG AAC G & $3897-3918$ \\
External antisense primer & GGA TAA TAT CGG CTT GGA AAG C & $4345-4366$ & 22 \\
Internal sense primer & CAA GAG AAG CTG ACA TCA GTG G & $4027-4048$ & 22 \\
Internal antisense primer & GAC AAT AGG TCC CTC TAC TTC G & $4146-4167$ & 22 \\
SVCV-AuNPs probe & GTC TAT CAT CAG CTA CAT CGC ATT CC & $3096-3121$ & 22 \\
\hline
\end{tabular}




\section{SVCV probe design}

All SVCV sequences available in the GenBank were aligned using Clustal $\mathrm{W}$ and a 26 bp specific probe designed to target the SVCV glycoprotein gene (Table 2). The specificity of the probe against other common aquatic viral pathogens sequences, including G-gene sequences and 1 complete genome sequence, FJ872827, of pike fry rhabdovirus (PFRV), deposited in GenBank was assessed using the basic local alignment search tool (BLAST).

\section{Colorimetric SVC-AuNP assay for detection of SVCV-RNA}

Different concentrations of $\mathrm{NaCl}(0.01$ to $1.0 \mathrm{M})$ and probe $(0.1$ to $3 \mu \mathrm{M})$ were tested to determine the optimum concentrations sufficient for visual detection of the colour change and, at the same time, appropriate for effective annealing of the probe to its target. The assay was performed as follows: $5 \mu \mathrm{l}$ of the extracted RNA were placed in a sterile PCR tube and $3 \mu$ of the hybridization buffer (10 $\mathrm{mM}$ phosphate buffer saline, pH 7.0, containing $0.4 \mathrm{M} \mathrm{NaCl}$ ) were added and the reaction mixture was completed to $10 \mu \mathrm{l}$ with sterile distilled water and mixed well. Optimal $\mathrm{pH}$, annealing temperature and time were also determined.

The mixture was denatured at $95^{\circ} \mathrm{C}$ for $30 \mathrm{~s}$, annealed at $58^{\circ} \mathrm{C}$ for $30 \mathrm{~s}$, and then cooled to room temperature for $10 \mathrm{~min}$. After addition of $10 \mu \mathrm{l}$ of colloidal AuNPs to the reaction mixture, the change in the solution colour was observed visually within $1 \mathrm{~min}$.

\section{Characteristics of the SVC-AuNPs assay}

Nucleic acids extracted from epizootic haematopoietic necrosis virus (EHNV), infectious haematopoietic necrosis virus (IHNV), infectious salmon anaemia virus (ISAV), koi herpes virus (KHV), viral hemorrhagic septicaemia virus (VHSV), PFRV, zander rhabdovirus (ZRV) and EPC cells were subjected to the SVC-AuNPs assay using the designed SVCV probe.

A 10-fold serial dilution of RNA extracted from SVCV grown in EPC culture with the titer of $10^{5}$ $\mathrm{TCID}_{50} \mathrm{ml}^{-1}$ (titers were measured according to Reed \& Muench 1938) were used to determine the lower detection limit of the SVC-AuNPs assay. Five microliters from each dilution were tested as described above.
The ability of the SVC-AuNPs assay to detect SVCV-RNA from clinical fish specimens was evaluated by testing 16 RNA samples extracted from SVCinfected fish tissue homogenate and 4 RNA samples extracted from healthy fish tissue homogenate. Test outcomes were compared with those of virus isolation. The same 20 samples were also assayed by the standard nRT-PCR assay and the results were then compared.

\section{RESULTS}

AuNPs were prepared using the citrate reduction method producing negatively charged nanoparticles. The negative charge due to citrate coating on the surface prevents aggregation of AuNPs and a red colour appears. Different concentrations of $\mathrm{NaCl}$ ( 0.1 to $1 \mathrm{M}$ ) were tested. The concentration of $\mathrm{NaCl}$ sufficient for both aggregation of AuNPs and proper annealing of the probe to its target was $0.4 \mathrm{M}$. Different concentrations of the probe $(0.1$ to $3 \mu \mathrm{M})$ were also used to determine the optimum probe concentration sufficient to stabilize the AuNPs in the presence of salt. A probe concentration less than $0.2 \mu \mathrm{M}$ did not prevent aggregation of AuNPs in the absence of the target. A final probe concentration more than $3 \mu \mathrm{M}$ was too high for any aggregation to occur in the presence of the target. Consequently, the hybridization buffer was prepared using $0.4 \mathrm{M}$ $\mathrm{NaCl}$ and $1.8 \mu \mathrm{M}$ probe in $10 \mathrm{mM}$ PBS, $\mathrm{pH}$ 7.0. Both the denaturation and annealing steps were necessary prior to the addition of the AuNPs to increase the specificity of the assay and to give reproducible results. Addition of AuNPs directly after removal of the tubes from the thermal cycler, while they were still hot, gave false positive results. Therefore, the mixture should stand at room temperature for 10 to 15 min prior to addition of AuNPs to obtain accurate results.

The probe designed in this study was highly specific to all SVCV sequences in GenBank and isolates used in this study. Moreover, it was not complementary to any aquatic viral RNAs as verified by BLAST searches of the GenBank database. The colour of the reaction mixture changed to blue in the presence of RNA extracted from all SVCV isolates used in this experiment after addition of the AuNPs. There was no colour change in the negative control reaction (Fig. 2). Correspondingly, no colour change was observed when RNAs extracted from EHNV, IHNV, ISAV, KHV, VHSV, PFRV, ZRV and EPC cells were subjected to the SVC-AuNPs assay, 


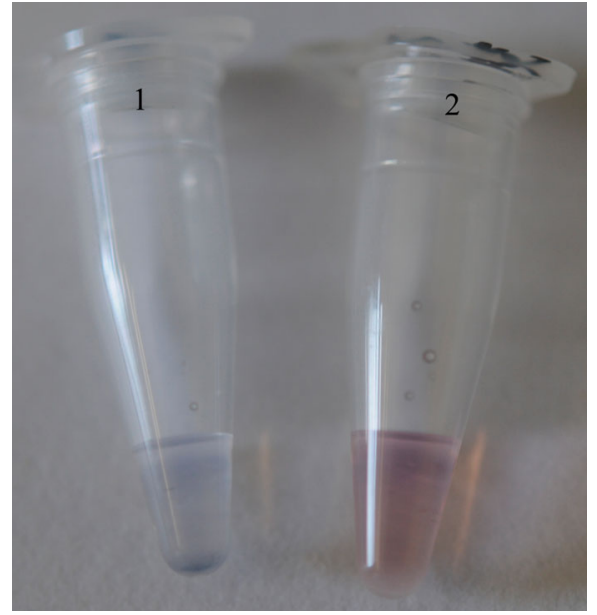

Fig. 2. Colorimetric spring viraemia of carp virus (SVCV)-RNA assay using unmodified gold nanoparticles (AuNPs). Each tube contains a $5 \mu \mathrm{l}$ sample, $1.8 \mu \mathrm{M}$ primer and $0.1 \mathrm{M} \mathrm{NaCl}$. Tube 1: SVCV-RNA tube, positive sample with blue colour. Tube 2: No template control tube, negative sample with red colour

Fig. 4. Agarose gel electrophoresis demonstrating the $141 \mathrm{bp}$ nested PCR products amplified from the spring viraemia of carp virus (SVCV)-RNA dilution series. Lane M: 100 bp DNA marker (Invitrogen); Lanes 1 to 10: nested PCR results using the following dilutions of SVCV-RNA: $10^{5}, 10^{4}, 10^{3}, 10^{2}, 10,10^{-1}, 10^{-2}, 10^{-3}$ $10^{-4}$ and $10^{-5} \mathrm{TCID}_{50} \mathrm{ml}^{-1}$ respectively. Nested PCR assay could detect SVCV-RNA as far as the $10^{-4}$ TCID $_{50} \mathrm{ml}^{-1}$ dilution (Lane 9)

which confirmed the specificity of the assay. Using a dilution series of RNA extracted from SVCV isolated in EPC culture, the developed AuNPs assay could detect SVCV until $10^{-3} \mathrm{TCID}_{50} \mathrm{ml}^{-1}$ (Fig. 3), compared to nRT-PCR that could detect SVCV until $10^{-4}$ TCID $_{50} \mathrm{ml}^{-1}$ (Fig. 4).

All SVCV isolates and 16 clinical samples used in this study tested positive with both the nRT-PCR and the developed SVCV-AuNPs assay. Positive results were confirmed by subsequent sequence analysis of the nRT-PCR product. The feasibility of the SVC-AuNPs assay to detect SVCV-RNA in fish tissues revealed a comparable performance to the nRT-PCR results (16 out of 16 for SVCV-positive samples and 4 out of 4 for negative samples) each of the 5 times the assays were executed. These results were also in agreement with those of virus isolation in cell culture.

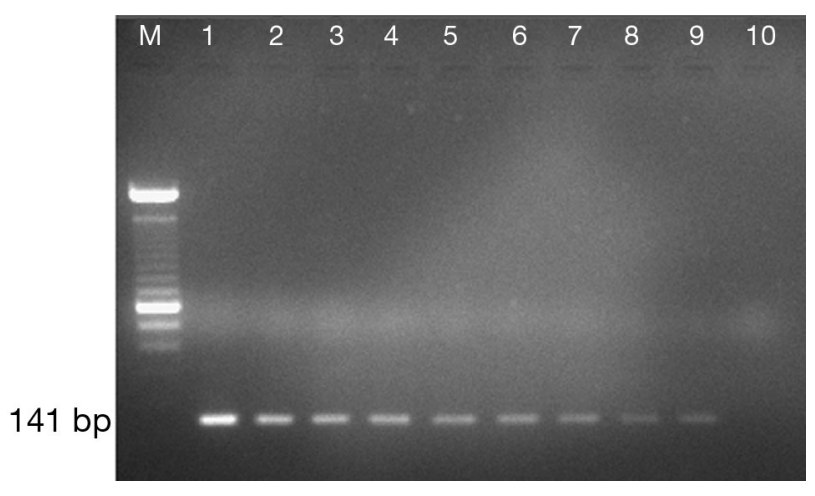

\section{DISCUSSION}

Fish diseases are a major problem in the aquaculture industry because of their financial impact (Savan et al. 2004). SVC is a transmissible disease of farmed fish that causes considerable economic losses (Koutná et al. 2003). Effective protection depends on rapid identification and elimination of infected individuals. Hence, rapid and specific diagnostic assays are crucial for timely and effective implementation of management measures in aquaculture facilities. Methods currently used for diagnosis of SVC have certain advantages and limitations, but in general they are complex, time consuming, labour intensive, expensive, and require specialized equipment and trained personnel. Colorimetric detection based on gold nanoparticles has been reported recently as an alternative to conventional diagnostic procedures because of its unique properties 
and broad applicability (Elghanian et al. 1997, Nam et al. 2003, Sato et al. 2003, Katz \& Willner 2004, Li \& Rothberg 2004, Rosi \& Mirkin 2005).

AuNPs in solution are typically stabilized by adsorbed negative citrate ions whose repulsion prevents the strong van der Waals attraction between gold particles from causing them to aggregate (Shaw 1992, Hunter 2001). Adsorption of ssDNA stabilizes the gold nanoparticles at concentrations of salt that would ordinarily induce aggregation of the gold colloids (Li \& Rothberg 2004). The adsorbing ssDNA supplies gold nanoparticles with a high density charge that prevents the aggregation induced by salt (Chen et al. 2010).

The developed SVC-AuNPs assay is based on visual comparison of reaction mixture colour before and after salt-induced AuNPs aggregation. The assay was successfully used for direct detection of SVCVRNA extracted from cell culture supernatants and infected fish tissue homogenates. Neither a reverse transcription nor an amplification step was required prior to detection. Furthermore, the hybridization of the unlabeled probe to its target RNA took place under optimized conditions ( $\mathrm{pH}$, temperature, time, and salt concentration) before addition of the AuNPs so that the kinetics and thermodynamics of the hybridization were unperturbed.

The probe used in the assay was derived from the sequence of the SVC glycoprotein gene which shows considerable variation among rhabdovirus species (Björklund et al. 1996). The probe sequence showed $100 \%$ homology with all SVCV isolate sequences available in GenBank. Homology of the selected oligonucleotide probe with common aquatic viral pathogens was excluded by sequence alignment with the GenBank database. Probe concentration was optimized to permit target ssDNA adsorption onto the AuNPs and prevent their aggregation. Probe concentrations that were too low had to be avoided because in the absence of the target, they were insufficient to prevent aggregation and led to false positive results. In contrast, in the presence of the target, a very high probe concentration would have prevented aggregation and led to false negative results. The evaluation of the specificity of the SVC-AuNPs assay indicated that it could detect RNA extracted from all examined isolates of SVCV in a reliable and highly specific manner without cross reactions with related viruses. The lower detection limit of the developed SVC-AuNPs assay was $10^{-3} \mathrm{TCID}_{50} \mathrm{ml}^{-1}$ of SVCVRNA. In order to obtain an indication of the assay's performance on clinical samples we compared the results of the optimized assay with the results of nested RT-PCR in detection of SVCV-RNA in in- fected fish samples. We found the performance of the developed assay was comparable to that of nRT-PCR (100\% concordance of 16 positive results and 100\% concordance of 4 negative results). These test outcomes also corresponded to those obtained by virus isolation in EPC culture. The colorimetric assay that was developed by Shawky et al. (2010) for direct detection of unamplified hepatitis C virus RNA using unmodified gold nanoparticles has a turnaround time of $30 \mathrm{~min}$ and eliminates the need for thermal cycling and detection instruments. However, the SVCAuNPs assay developed in this study requires only 15 min to be carried out and needs only a heating block or a water bath to be performed.

In conclusion, the developed assay has an acceptable sensitivity, is specific, rapid, and cost effective. The price of enough gold chloride to prepare 11 of $15 \mathrm{~nm}$ gold nanoparticles is about 200 Euros where only $10 \mu \mathrm{l}$ are needed per assay. Unused gold nanoparticle solution can be stored for several years in a brown bottle (McFarland et al. 2004). Positive results can be observed visually within 1 min after addition of the AuNPs. Furthermore, covalent functionalization of the gold, the probe, or the target nucleic acid is not required. The assay is performed in a single tube, which reduces carryover contamination and facilitates simultaneous testing of many samples. Moreover, RT-PCR and post-PCR analyses such as gel electrophoresis are not required in this method. Neither a fluorescent probe nor a DNA-binding dye is needed for detection. This methodology should therefore find wide application in fish farms and aquaculture laboratories. Given the assets of the nanogold assay in the determination of SVCV, this method can be applied to diagnose other pathogens, which pose serious threats to the aquaculture industry

Acknowledgements. The authors are very grateful to D. Fichtner and S. Bergmann from the Friedrich-Loeffler-Institut, Insel Riems, Germany, for providing pike fry rhabdovirus and zander rhabdovirus for specificity testing. The authors thank M. W. Stock for his technical assistance and photography.

\section{LITERATURE CITED}

Ahne W, Björklund HV, Essbauer S, Fijan N, Kurath G, Winton JR (2002) Spring viremia of carp (SVC). Dis Aquat Org 52:261-272

Amos KH (1985) Procedures for the detection and identification of certain fish pathogens, 3rd edn. Fish Health Section, American Fisheries Society, Bethesda, MD

Bachmann PA, Ahne W (1973) Isolation and characterization of agent causing swim bladder inflammation in carp. Nature 244:235-237

Björklund HV, Higman KH, Kurath G (1996) The glycoprotein genes and gene junctions of the fish rhabdoviruses 
spring viremia of carp virus and hirame rhabdovirus: analysis of relationships with other rhabdoviruses. Virus Res 42:65-80

Bloomfield VA, Crothers DM, Tinoco I Jr (1999) Nucleic acids: structures, properties, and functions. University Science Books, Sausalito, CA

Bovo G, Giorgetti G. Jergenson PEV, Olesen NJ (1987) Infectious haematopoietic necrosis: flrst detection in Italy. Bull Eur Assoc Fish Pathol 7:124

> Chen Z, He Y, Luo S, Lin H and others (2010) Label-free colorimetric assay for biological thiols based on ssDNA/ silver nanoparticle system by salt amplification. Analyst 135:1066-1069

> Daniel MC, Astruc D (2004) Gold nanoparticles: assembly, supramolecular chemistry, quantum-size-related properties, and applications toward biology, catalysis, and nanotechnology. Chem Rev 104:293-346

- Elghanian R, Storhoff JJ, Mucic RC, Letsinger RL, Mirkin CA (1997) Selective colorimetric detection of polynucleotides based on the distance-dependent optical properties of gold nanoparticles. Science 277:1078-1081

Fijan N, Petrinec Z, Sulimanović Đ, Zwillenberg LO (1971) Isolation of the viral causative agent from the acute form of infectious dropsy of carp. Vet Arh 41:125-138

Garver KA, Dwilow AG, Richard J, Booth TF, Beniac DR, Souter BW (2007) First detection and confirmation of spring viraemia of carp virus in common carp, Cyprinus carpio L., from Hamilton Harbour, Lake Ontario, Canada. J Fish Dis 30:665-671

Goodwin AE (2002) First report of spring viremia of carp virus (SVCV) in North America. J Aquat Anim Health 14: 161-164

> Grabar KC, Freeman RG, Hommer MB, Natan MJ (1995) Preparation and characterization of Au colloid monolayers. Anal Chem 67:735-743

> Huber M, Wei TF, Müller UR, Lefebvre PA, Marla SS, Bao YP (2004) Gold nanoparticle probe-based gene expression analysis with unamplified total human RNA. Nucleic Acids Res 32:e137

Hunter RJ (2001) Foundations of colloid science, 2nd edn. Oxford University Press, New York, NY

> Jain PK, Lee KS, El-Sayed IH, El-Sayed MA (2006) Calculated absorption and scattering properties of gold nanoparticles of different size, shape, and composition: applications in biological imaging and biomedicine. J Phys Chem B 110:7238-7248

Jung YL, Jung C, Parab H, Li T, Park HG (2010) Direct colorimetric diagnosis of pathogen infections by utilizing thiol-labeled PCR primers and unmodified gold nanoparticles. Biosens Bioelectron 25:1941-1946

Katz E, Willner I (2004) Integrated nanoparticle-biomolecule hybrid systems: synthesis, properties, and applications. Angew Chem Int Ed 43:6042-6108

Koutná M, Vesely T, Psikal I, Hulová J (2003) Identification of spring viraemia of carp virus (SVCV) by combined RTPCR and nested PCR. Dis Aquat Org 55:229-235

Langdon JS, Humphrey JD, Williams L, Hyatt AD, Westbury HA (1986) First virus isolation from Australian fish: an iridovirus-like pathogen from redfin perch, Perca fluviatilis L. J Fish Dis 9:263-268

> Lee JH, Wang Z, Liu J, Lu Y (2008) Highly sensitive and selective colorimetric sensors for uranyl $\left(\mathrm{UO}_{2}{ }^{2+}\right)$ : development and comparison of labeled and label-free DNAzyme-gold nanoparticle systems. J Am Chem Soc 130:14217-14226

Li H, Rothberg L (2004) Colorimetric detection of DNA sequences based on electrostatic interactions with unmodified gold nanoparticles. Proc Natl Acad Sci USA 101:14036-14039

Li H, Rothberg L (2005) Detection of specific sequences in RNA using differential adsorption of single-stranded oligonucleotides on gold nanoparticles. Anal Chem 77: 6229-6233

Liu H, Gao L, Shi X, Gu T, Jiang Y, Chen H (2004) Isolation of spring viraemia of carp virus (SVCV) from cultured koi (Cyprinus carpio koi) and common carp (C. carpio carpio) in P.R. China. Bull Eur Assoc Fish Pathol 24:194-202

McFarland AD, Haynes CL, Mirkin CA, Van Duyne RP, Godwin HA (2004) Color my nanoworld. J Chem Educ 81:544A

> Mirkin CA, Letsinger RL, Mucic RC, Storhoff JJ (1996) A DNA-based method for rationally assembling nanoparticles into macroscopic materials. Nature 382:607-609

Nam JM, Thaxton CS, Mirkin CA (2003) Nanoparticlebased bio-bar codes for the ultrasensitive detection of proteins. Science 301:1884-1886

OIE (Office International des Epizooties) (2009) Diagnostic manual for aquatic animal diseases, 6th edn. OIE, Paris

Olesen NJ, Lorenzen N, Jørgensen PEV (1993) Serological differences among isolates of viral haemorrhagic septicaemia virus detected by neutralizing monoclonal and polyclonal antibodies. Dis Aquat Org 16:163-170

Oreshkova SF, Shchelkunov IS, Tikunova NV, Shchelkunova TI, Puzyrev AT, Ilyichev AA (1999) Detection of spring viremia of carp virus isolates by hybridization with non-radioactive probes and amplification by polymerase chain reaction. Virus Res 63:3-10

Reed LJ, Muench H (1938) A simple method of estimating fifty per cent endpoints. Am J Hyg 27:493-497

Rosi NL, Mirkin CA (2005) Nanostructures in biodiagnostics. Chem Rev 105:1547-1562

Sato K, Hosokawa K, Maeda M (2003) Rapid aggregation of gold nanoparticles induced by non-cross-linking DNA hybridization. J Am Chem Soc 125:8102-8103

Savan R, Igarashi A, Matsuoka S, Sakai M (2004) Sensitive and rapid detection of Edwardsiellosis in fish by a loopmediated isothermal amplification method. Appl Environ Microbiol 70:621-624

Shaw DJ (1992) Introduction to colloid and surface chemistry, 4th edn. Butterworth-Heinemann, Oxford

> Shawky SM, Bald D, Azzazy HME (2010) Direct detection of unamplified hepatitis C virus RNA using unmodified gold nanoparticles. Clin Biochem 43:1163-1168

Storhoff JJ, Lazarides AA, Mucic RC, Mirkin CA, Letsinger RL, Schatz GC (2000) What controls the optical properties of DNA-linked gold nanoparticle assemblies? J Am Chem Soc 122:4640-4650

Teng Y, Liu H, Lv JQ, Fan WH, Zhang QY, Qin QW (2007) Characterization of complete genome sequence of the spring viremia of carp virus isolated from common carp (Cyprinus carpio) in China. Arch Virol 152:1457-1465

> Thaxton CS, Georganopoulou DG, Mirkin CA (2006) Gold nanoparticle probes for the detection of nucleic acid targets. Clin Chim Acta 363:120-126

Watson JD (1968) The double helix: a personal account of the discovery of the structure of DNA. Atheneum, New York, NY

Yue Z, Teng Y, Liang C, Xie X and others (2008) Development of a sensitive and quantitative assay for spring viremia of carp virus based on real-time RT-PCR. J Virol Methods 152:43-48 